The Economic and Social Review, Vol. 40, No. 1, Spring, 2009, pp. 49-71

\title{
Non-cash Benefits and the Distribution of Economic Welfare*
}

\author{
TIM CALLAN \\ CLAIRE KEANE \\ The Economic and Social Research Institute, Dublin
}

\begin{abstract}
Non-cash benefits can have substantial effects on the distribution of economic welfare. Standard approaches to the inclusion of non-cash benefits in broader measures of resources have failed to take adequate account of the pattern of needs associated with the greater use of health and education services. Our results, for Ireland in the year 2000, show that it is possible to derive more appropriate measures of total resources than have been derived using standard methods. The results indicate that the greatest impact comes from the inclusion of imputed rent for owner occupation as part of the resource measure. When this is done, the rate of "resource poverty" for older people is substantially reduced, in line with results which use indicators of standard of living as well as cash incomes ("consistent poverty").
\end{abstract}

\section{INTRODUCTION}

Studies of income distribution and inequality are based, for the most part, Oon cash incomes. Cash incomes, however, are only a partial measure of the resources that generate economic welfare. Non-cash incomes from different sources are substantial in aggregate terms, and vary widely across the population in a given country. Furthermore, the issue of non-cash income can be particularly important when undertaking comparisons between countries as the extent and nature of goods and services provided free or at subsidised rates can differ greatly from one country to another.

* This paper builds on research undertaken as part of a project on Accurate Income Measurement for the Assessment of Policy, funded under the Sixth Framework Programme. We are grateful to colleagues in this project for helpful comments, and to participants at an ESRI seminar in February 2008.

Paper delivered at the Twenty-Second Annual Conference of the Irish Economic Association, Westport, Co. Mayo, 25-27 April, 2008. 
In this paper we re-examine the ways in which studies of economic inequality have taken non-cash resources into account. A number of influential studies follow a measurement approach which values the benefit of a non-cash service at the cost of its provision. This tracks the use of resources attributable to different individuals and households. However, the results on resource use are then interpreted as measuring the economic welfare of the households concerned. We argue that this is not appropriate, as it fails to take into account differences in need which are strongly associated with the variation in resources. We propose alternative measures which are applied to Irish data (from the Living in Ireland Survey, 2000). Our analysis covers three of the largest sources of in-kind income:

- imputed rent arising from owner-occupied housing;

- benefits arising from free health services; and

- benefits arising from state-provided or subsidised education.

The remainder of the paper is structured as follows. Section II reviews key studies on the impact of non-cash resources on inequality, and points to the importance of keeping the end-goal of improving the measure of welfare in mind when deciding on the measurement approach. Sections III, IV and V deal with the issues involved in applying this approach in an Irish context. Section III covers the inclusion of imputed rent for owner-occupiers; Section IV deals with the inclusion of health services; and Section V deals with issues arising in the inclusion of education. Section VI combines these analyses to provide a resource measure including cash incomes, imputed rent, health services and education. The main findings are drawn together in Section VII.

\section{CONCEPTUAL AND MEASUREMENT ISSUES}

Standard practice in the analysis of the distributional impact of publicly provided services is based on two key assumptions (see, for example, Jones (2006), Marical et al. (2006) and Smeeding et al. (1993)):

1. The analysis of incidence is conducted on a static basis, and excludes externalities. ${ }^{1}$

2. The value of the transfer to the beneficiary is assumed to be equal to the average cost of producing the relevant service.

${ }^{1}$ Put another way, it is assumed that the only recipients of the relevant service benefit from it (though this may improve the household's position) - and that provision of the service does not create any benefits or losses to the non-recipients (e.g., through tax financing - so it is assumed that the taxes financing the transfers are already in place). 
Each of these assumptions has been questioned in the literature. For example, Smeeding et al. (1993) note that the average cost of provision may overstate the value of the non-cash benefit, as recipients might, if they had the corresponding cash amount instead, prefer to spend some of it on other goods and services. O'Higgins (1981) provides an illustration of a further difficulty with the "cost per capita" method. If, for example, education benefits were measured on the basis of the cost of provision, then a rise in the wages of teachers would lead to a higher estimate of the value of the service to the individual. But under these circumstances, the "output" of the service could be unchanged, so that there would be no real gain to the beneficiary, despite the rise in the benefit as measured by the "cost per capita" approach. A further consideration, somewhat countering the first, is that economies of scale may mean that services purchased "in bulk" by the state are less costly than what individuals could purchase in the market - in which case the value could be greater than under the cost of provision approach.

Despite such criticisms, the attribution of benefit based on cost of provision has remained very common in this literature. There are, however, even more fundamental criticisms of the standard approach to which we now turn, and with which we try to deal in our empirical work.

In the case of public health care subsidies the imputation of non-cash income is often based on a risk-related insurance approach. Each individual is assumed to receive a benefit from the state determined by the average spending on his/her age-sex group, ${ }^{2}$ irrespective of what use was actually made of public health services. This approach (used by Saunders et al. (1991), Donaldson et al. (2002) and Garfinkel et al. (2004)) can be seen as an estimate of an actuarially fair insurance premium. These benefits are then added to cash incomes to provide a broader measure of resources.

An insurance based approach is seen as preferable to one based on the actual use of services, under which the greatest benefit would be attributed to those who make greatest use of health services. An "actual use" approach would imply the individuals who are most often and most severely ill, and in need of health services, could have "total resources" many times greater than their cash incomes. The implication, when basing studies of distribution on such a measure would be that many very ill individuals would be ranked as higher in the distribution of "total resources" than their healthy counterparts. While this makes sense in terms of tracking the use of resources, it is not appropriate in terms of measuring welfare: it would not be reasonable to

2 Adjustments may also be made with respect to the socio-economic group of the individual, or taking into account particular institutional features of the public health system and its interaction with private sector provision of health services and insurance. 
describe a person as 'better off' because they were sick and in need of medical treatment which they received for free. Studies of income and resource distribution aim to rank individuals in terms of welfare, and already take account of the needs of households of different sizes and compositions by means of adult equivalence scales. When health resources are taken into account, corresponding needs in terms of health must also be brought into the analysis.

Does the "insurance-based" approach manage to overcome this critique? We argue, following Radner (1997), that it does not. The insurance based approach, when linked to age, means that benefits vary sharply according to age group. Again, this is because health status and health service usage are closely linked to age. ${ }^{3}$ While there is some "smoothing" compared to the actual use approach, the fundamental point remains. Radner points out the inconsistency between income and needs when it comes to attributing noncash resources to individuals. For example, the inclusion of Medicare in the income of the aged can result in an upward bias of their economic status. $\mathrm{He}$ also points out that the equivalence scale (reflecting needs) used for cash income may not be appropriate when non-cash income is included in the definition of resources, as the receipt of non-cash incomes may be associated with particular needs. He concludes that failure to adjust the equivalence scale to take account of additional needs tends to overestimate the economic status of the aged. The equivalence scales estimated by Jones and O'Donnell (1995) for those with a disability carry a similar implication - the needs of those with a disability are greater, so their cash and non-cash resources would need to be adjusted to take this into account for welfare comparison purposes.

Parallel arguments can be applied in the case of education. If non-cash incomes are assigned on the basis of cost of provision in respect of each pupil or student in first-, second- and third-level education, then the relative position of families with children appears to improve. But the adult equivalence scales generally used do not take into account children's need for education. This is eminently reasonable, given that in most industrial economies, education is both compulsory and free, at least up to the mid-teens. How then should equivalence scales be adjusted to take into account children's need for education? One approach would be that for the years in which education is compulsory and free, children have a need for education which is equal to that provided by the free system. On this basis, state subsidies for the compulsory education years would not be seen as improving the relative

\footnotetext{
${ }^{3}$ For present purposes, it does not matter whether this is a pure age gradient, or linked to intensive care in the year or two before death.
} 
welfare of students or their families. But state subsidies to post-compulsory education (in upper second level and third level) would affect relative welfare.

What of results based on the standard approach? Here we limit our focus to the UK and Ireland. In the UK, Evandrou et al. (1992) use UK data and looks at public spending on education, health services and subsidies to local authority housing. They find that the three benefits combined are worth most in the middle of the distribution with education being mildly 'pro-rich', particularly that of tertiary education. Sefton (2002) estimates the 'social wage' for the UK using 1996/97 and 2000/01 data and compares it to 1979. It shows that poorer households receive a greater proportion of welfare non-cash benefits than richer households and the 'pro-poor bias' has increased over time. This has not succeeded in reducing inequality however.

In the Irish context, there are a number of studies based on the standard "cost of provision" approach, applied inter alia to health and education. O'Connell (1982) looked at the tax-benefit system in Ireland, including noncash benefits such as education, housing, food subsidies and free public transport. In general it was seen to be progressive with households with more than two adults and children benefiting the most. Educational benefits were found to be regressive however. Nolan (1981) also looked at the Irish system and found that the value of non-cash benefits (such as medical services, housing and education) appeared relatively stable across income groups falling only marginally as income rose. This contrasted with cash benefits, which favoured lower income households. Rottman and Reidy (1988) examined the redistributive effect of government spending on areas such as education, housing and health during the 1970s. They found that spending on healthcare became more redistributive over the 1970s. Primary education expenditure in the 1970s was found to be redistributive but third level spending was strongly regressive, particularly in universities compared to other third level institutions. Regarding housing, the benefit associated with the provision of local authority housing became more progressive over the seventies - in part because of the self-selection involved in tenant purchase schemes.

Nolan and Russell (2001) look at a range of non-cash benefits in Ireland, including the 'free schemes' such as free travel, free electricity etc. They found that the medical card scheme was strongly concentrated towards the bottom end of the distribution with 61 per cent of medical card spending going towards the bottom 30 per cent of the income distribution.

Our results, provided in the following sections, are based on a different approach to the estimation of benefits, with a careful eye to the overall implications for economic welfare, and for a more recent period. The dataset used is the Living in Ireland Survey for the year 2000. It is the Irish component of the European Community Household Panel (ECHP). The 
baseline quintiles are constructed using equivalised, disposable income. The equivalence scale used is the modified OCED equivalence scale which attributes a value of 1 to the first adult, .5 to subsequent adults and .3 for children.

Regarding inequality and poverty measures we report the Gini coefficient, the Atkinson index with inequality aversion parameters set at 0.5 and 1.5 and the Foster-Greer-Thorbecke poverty indices (FGT). The Gini is the ratio of the gap between the Lorenz curve and the line of perfect equality (45 degree line) to the entire area under the 45 degree line. It is bounded between 0 and 1,0 corresponding to perfect equality, 1 corresponding to perfect inequality. A fall in the Gini therefore signifies a fall in inequality. The Atkinson indices are also measures of inequality but have the added advantage of being a normative measure through the choice of epsilon, which allows a greater weight to be given to different parts of the income distribution. We use 0.5 and 1.5 as our values of epsilon, 0.5 is more sensitive to changes at the upper end of the income distribution, 1.5 to the lower end of the income distribution. Moving on to the FGT poverty measures, the FGT 0 is the head count index of poverty and tells us the percentage of people with incomes below the poverty line. The FGT 1 is a measure of the poverty gap ratio, combining information about the extent and the depth of poverty i.e., how far people fall below the poverty line. Finally, the FGT 2 measure is a "depth and distribution sensitive" measure, which gives greater weight to those with incomes furthest below the poverty line.

\section{IMPUTED RENT FROM OWNER OCCUPATION}

Housing represents a substantial element of household wealth, and households that own their own accommodation have an income advantage over those that have to pay rent. As part of our investigation of aspects of noncash income, therefore, we seek to adjust income measures to take into account the "imputed rent" enjoyed by owner-occupiers. One method used for such adjustment is the 'before housing costs' and 'after housing costs' measures of income, as used in the UK's official analyses of poverty and income distribution (Households Below Average Income) and by Fahy et al. (2004). Expenditure on rent and mortgages is deducted from household income, doing away with the need to estimate the "imputed income" derived from owning your own house mortgage free or receiving rent subsidies. While this method has the merit of simplicity, and can be used to identify some of the key features, it fails to take account of the fact that households vary in the strength of their preferences for housing, so that a post-housing costs measure is also an imperfect measure of welfare. 
Census data show high rates of home ownership in Ireland. As a result, the issue of imputed rent from owner occupation is particularly important in an Irish context. Within the Living in Ireland Survey for 2000 almost 85 per cent of people in the sample are living in owner-occupied accommodation (whether owned outright or owned with a mortgage).

Frick and Grabka (2003) identify three methods for calculating imputed rent:

- The capital market approach.

- The market rent approach.

- The opportunity cost approach.

Frick and Grabka assess the three approaches, and conclude that the opportunity cost method offers significant advantages. In the Irish context, the dominance of owner occupation as a mode of tenure and the size of the sample (3,463 households) means that there are just 114 (unweighted) cases of private sector rented households on which the opportunity cost method depends to establish relationships between indicator variables and market rents. This would be a rather shaky basis on which to construct empirical estimates. By contrast, information on the capital value of the house is gained for more than 80 per cent of the sample. In these circumstances it seems prudent to apply the capital market approach and it is this approach we use here. The value of the house is self-assessed by the head of the household. If no figure is given we use the interviewer estimate of the house value. From this we deduct the outstanding mortgage value if the house is not owned outright. Callan (1992) found that self-assessed values corresponded well with interviewer estimates of housing values. Table 1 reports the distribution of housing values of owneroccupied housing as of 2000 . The second column shows the total housing value, the third column shows the housing value net of the outstanding mortgage amount (net equity). We see that house values rise with income. We use an imputed rent of 3 per cent of the homeowner's net equity in the property, following the procedures of Frick and Grabka. The fact that owner occupation is the predominant mode of tenure means that analysing just owner-occupiers will capture about 90 per cent of the total impact of imputed rent across all tenures.

Figure 1 shows the average house prices within and outside of Dublin from 2000 on. We can see large growth in the average house price since 2000. House prices in Dublin in 2000 stood at 57 per cent of the 2007 value and 74 per cent of the 2007 value for houses outside of Dublin. Since then, there have been sharp falls in house prices, continuing at the time of writing. It seems likely, 
Table 1: Average Housing Values by Quintile

\begin{tabular}{lcc}
\hline \hline Quintile & House Value & Net Equity \\
\hline 1 & 69,215 & 63,661 \\
2 & 98,642 & 90,871 \\
3 & 121,941 & 110,584 \\
4 & 155,773 & 140,832 \\
5 & 185,783 & 162,556 \\
All & 126,390 & 113,807 \\
\hline
\end{tabular}

therefore, that house values in 2000 were closer to a long-run sustainable level and are, therefore, a suitable basis for the estimation of the impact of imputed rent on resource distribution.

Figure 1: Average House Prices, 2000-2007

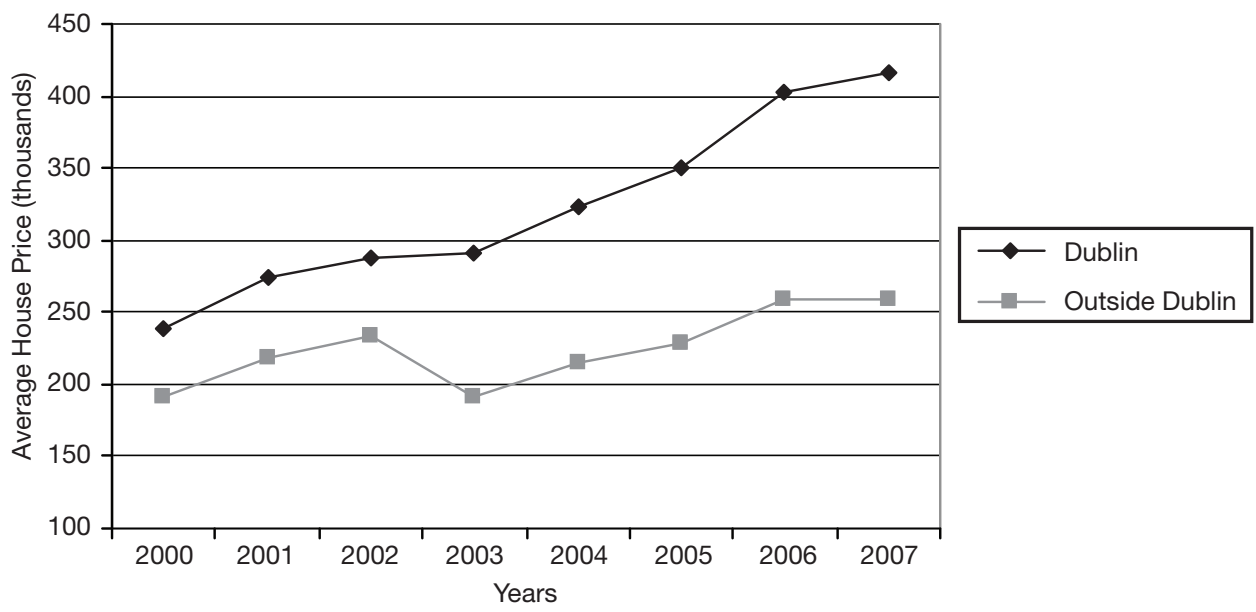

Source: Permanent TSB/ESRI House Price Index.

Table 2 shows the income shares by quintile of disposable income per adult equivalent before (column 2) and after (column 3) imputed rent is considered. The income share of the lowest and middle quintiles increase with a fall in the income share at the top of the income scale. We can see from the last column that the percentage increase in equivalised disposable income is largest for the bottom quintile and decreases as we move up the income distribution. ${ }^{4}$

${ }^{4}$ Some measure of the impact of capital gains from the appreciation of housing over periods of strong price growth could be gained from using a higher rate of return. Similar patterns are observed with a higher rate of return to housing of 5 per cent. Imputed rent then forms almost 17 per cent of average income, and close to 30 per cent of the initial cash income of the bottom quintile. 
Table 2: Changes in Income Shares by Quintile Due to Imputed Rent

\begin{tabular}{lccc}
\hline \hline Quintile & $\begin{array}{c}\text { Equivalised } \\
\text { Disposable Income } \\
\text { Share }\end{array}$ & $\begin{array}{c}\text { Income } \\
\text { Share Post } \\
\text { Transfer } \\
\%\end{array}$ & $\begin{array}{c}\text { Percentage Change in } \\
\text { Equivalised } \\
\text { Disposable Income } \\
\%\end{array}$ \\
\hline 1 & 7.8 & 8.2 & 17.4 \\
2 & 12.9 & 12.9 & 12.2 \\
3 & 17.9 & 18.0 & 10.1 \\
4 & 23.6 & 23.5 & 10.0 \\
5 & 37.8 & 37.4 & 8.0 \\
Total & 100 & 100 & 10.1 \\
\hline \hline
\end{tabular}

Table 3 shows the effects on various measures of inequality (the Gini coefficient, and the Atkinson index with values of 0.5 and 1.5) and relative income poverty (the Foster Greer Thorbecke indices of the head count, poverty gap ratio, and their distribution sensitive measure, all evaluated at 60 per cent of median income per adult equivalent) 5 . All the inequality indices show a fall, albeit no more than 3 per cent in the case of the Gini, which is particularly sensitive to changes in the middle of the distribution. But the Atkinson measure with the index of 1.5, and the poverty measures (FGT) are more sensitive to changes at the bottom of the distribution and show a greater fall - of between 11 and 15 per cent in the case of the FGT indices.

Table 3: Impact of Imputed Rent on Inequality of Resources

Index

Value of the Index

\begin{tabular}{lccc} 
& $\begin{array}{c}\text { Disposable } \\
\text { Cash Income }\end{array}$ & $\begin{array}{c}\text { Disposable Income } \\
\text { Plus Imputed Rent }\end{array}$ & $\begin{array}{c}\text { Change } \\
\%\end{array}$ \\
\hline Gini & 0.302 & 0.293 & -3.0 \\
Atkinson 0.5 & 0.074 & 0.070 & -6.0 \\
Atkinson 1.5 & 0.247 & 0.219 & -11.5 \\
FGT0 (poverty head count) & 0.219 & 0.194 & -11.4 \\
FGT1 (poverty gap ratio) & 0.053 & 0.046 & -13.3 \\
FGT2 (depth and distribution & & & -14.8 \\
$\quad$ sensitive measure) & 0.019 & 0.016 & - \\
\hline \hline
\end{tabular}

5 This is the cut-off given most prominence in the EU's Laeken indicators; in EU terminology it is the "at risk of poverty" indicator. The equivalence scale is 1 for the first adult in a household, .5 for other adults, and .3 for children. 


\section{HEALTH SERVICES AND THE DISTRIBUTION OF ECONOMIC WELFARE}

In 2000 , the year to which the data refer, total Irish healthcare spending stood at 6.3 per cent of GDP. A brief description of the system is needed as a context for our analysis. Hospital care was free to all except for a statutory charge of $€ 33$ per night up to a maximum of $€ 330$ over 12 months. Low income individuals and families with incomes below specified limits were entitled to a medical card. Medical cardholders obtained extra services (such as GP consultations and prescription drugs) free of charge and did not have to pay for hospital treatment. General practitioner costs are not covered by the State if the person does not have a medical card. The drugs payment scheme, introduced in 1999, meets the cost of prescription medicine above a certain monthly rate which the household must bear themselves. In 2000 this rate stood at just over $€ 53$ per month. Private health insurance cover was available, and premia for health insurance were eligible for tax relief. Medical costs not covered by health insurance were also eligible for tax relief.

Table 4 shows the sources of financing for health expenditure for the year 2000. We see that the majority of healthcare spending is funded by the government (72.4 per cent). Out-of-pocket payments made up 13.5 per cent of healthcare spending and private insurance covered nearly 8 per cent.

Table 4: Sources of Financing of Health Expenditure in Ireland, 2000

\begin{tabular}{lc}
\hline \hline Finance Source & \% of Health Expenditure \\
\hline Government & 72.4 \\
Social Security Schemes & 0.9 \\
Out-of-pocket payments & 13.5 \\
Private Insurance & 7.6 \\
All Other Private Funds & 5.6 \\
\hline \hline
\end{tabular}

Source: OECD Health Data 2002 4th edition.

We first apply the insurance-based approach and attribute a value to the health transfers made. Table 5 shows the value of the healthcare transfer made by income quintile. The value of the transfer is greatest for the lowest income quintile, falling somewhat for each higher quintile. The income share of the bottom two quintiles increases slightly if the "health transfer" is included as a part of income. There is a slight fall in the income share of the third and fourth quintiles but the income share of the top quintile remains unchanged. 
Table 5: Changes in Incomes and Income Shares by Quintile Due to All Health Transfers

\begin{tabular}{|c|c|c|c|c|c|}
\hline Quintile & $\begin{array}{l}\text { Household } \\
\text { Equivalent } \\
\text { Income }\end{array}$ & $\begin{array}{l}\text { Health } \\
\text { Transfer }\end{array}$ & $\begin{array}{c}\text { Household } \\
\text { Equivalent } \\
\text { Income Including } \\
\text { Health Transfer }\end{array}$ & $\begin{array}{c}\text { Income } \\
\text { Share } \\
\text { Pre-Transfer }\end{array}$ & $\begin{array}{c}\text { Income } \\
\text { Share } \\
\text { Post-Transfer }\end{array}$ \\
\hline & $€$ & $€$ & $€$ & $\%$ & $\%$ \\
\hline 1 & 121.80 & 44.94 & 166.74 & 8 & 10 \\
\hline 2 & 198.50 & 40.43 & 238.93 & 13 & 14 \\
\hline 3 & 275.47 & 38.00 & 313.47 & 18 & 18 \\
\hline 4 & 363.93 & 36.30 & 400.23 & 24 & 23 \\
\hline 5 & 584.38 & 34.27 & 618.65 & 38 & 36 \\
\hline Total & 309.07 & 38.78 & 347.84 & 20 & 20 \\
\hline
\end{tabular}

All of the poverty and inequality measures listed in Table 6 show a fall if the health transfer is included as part of income. The fall in the poverty indices is particularly marked, with a reduction of between one-third and half for the poverty rate (head count measure) and the depth and distribution sensitive measure respectively.

Table 6: Impact of Health Expenditure on Inequality of Resources

\begin{tabular}{|c|c|c|c|}
\hline \multirow[b]{2}{*}{ Inequality and Poverty Indices } & \multicolumn{3}{|c|}{ Value of the Index } \\
\hline & $\begin{array}{c}\text { Pre-health } \\
\text { Transfer }\end{array}$ & $\begin{array}{c}\text { Post-health } \\
\text { Transfer }\end{array}$ & $\begin{array}{c}\text { Change } \\
\%\end{array}$ \\
\hline Gini & 0.302 & 0.264 & -12.6 \\
\hline Atkinson 0.5 & 0.074 & 0.056 & -23.7 \\
\hline Atkinson 1.5 & 0.247 & 0.158 & -36.0 \\
\hline Poverty Rate (FGT0) & 0.219 & 0.148 & -32.4 \\
\hline Normalised Poverty Gap (FGT1) & 0.053 & 0.030 & -43.2 \\
\hline $\begin{array}{l}\text { FTG2 (Depth and distribution } \\
\text { sensitive measure) }\end{array}$ & 0.019 & 0.009 & -51.9 \\
\hline
\end{tabular}

As noted above, the insurance-based approach used here still has some of the drawbacks associated with the "actual use" approach (cf Radner, 1997). This approach overstates the welfare of the elderly in particular, as it attributes high benefits to them but does not take account of their greater health needs. 
An alternative is to focus on those elements of health system that do genuinely affect the distribution of resources and welfare. Chief among these is the medical card system, which uses a means-test to focus resources on low income families and individuals. ${ }^{6}$ The medical card entitles the holder to free GP services, prescription medicines, in-patient hospital services, out-patient services, dental, optical and aural services, maternity and infant care services as well as some personal and social care services. A means-test is carried out and those within the financial guidelines can receive a medical card. Those whose income falls above the guideline amount but for whom the cost of medical care would cause 'undue hardship' can also be entitled to a medical card. We focus on the 35 per cent of the population who receive a medical card and use the cost per capita basis to attribute a value to them. This is done by taking the total spent per capita in 2000 by the government on the medical card scheme (reducing the amount spent on drugs and medicines in line with that allowable under the Drugs Payment Scheme which is open to all nonmedical cardholders). A more detailed breakdown of spending on the General Medical Service (GMS) is shown in the Appendix. Table 7 shows the percentage of households who have one or more residents covered by a medical card by income quintile. As expected medical card coverage is concentrated in the lower income quintiles and falls as we move up the income distribution.

Table 7: Medical Coverage by Quintile

\begin{tabular}{lc}
\hline \hline Quintile & $\begin{array}{c}\text { \% of Households Covered by } \\
\text { Medical Card }\end{array}$ \\
\hline 1 & 85 \\
2 & 62 \\
3 & 34 \\
4 & 15 \\
5 & 5 \\
\hline \hline
\end{tabular}

Table 8 shows us the income shares per quintile before and after the medical card value is taken into account. The income shares of the lower quintiles increase with a reduction in the middle and top quintile. We see very small increases (less than half a per cent) in the equivalised disposable income of the top two quintiles, while the bottom and second quintile see average increases of 11.9 and 4 per cent respectively.

${ }^{6}$ It should be noted that, given the association between low income and ill-health, the health need of the medical card population is itself greater than that of the population not entitled to a medical card. We do not attempt to adjust for this difference, but results from Layte et al. (2007) indicate that the extent of the difference is far less than the age gradient in health need. Further adjustment for the income-health gradient would strengthen the conclusions arrived at here. 
Table 8: Changes in Incomes and Income Shares by Quintile Due to Medical Card Expenditure

\begin{tabular}{lccc}
\hline \hline Quintile & $\begin{array}{c}\text { Equivalised Disposable } \\
\text { Income Share }\end{array}$ & $\begin{array}{c}\text { Income Share } \\
\text { Post-Transfer }\end{array}$ & $\begin{array}{c}\text { Percentage Change } \\
\text { in Equivalised } \\
\text { Disposable Income } \\
\%\end{array}$ \\
\hline 1 & $\%$ & $\%$ & 11.9 \\
2 & 7.8 & 8.6 & 4.0 \\
3 & 12.9 & 13.2 & 1.6 \\
4 & 17.9 & 17.5 & 0.5 \\
5 & 23.6 & 23.5 & 0.1 \\
Total & 37.8 & 37.3 & 1.9 \\
\hline \hline
\end{tabular}

Table 9 shows the inequality and poverty indicators before and after the transfer is taken into account. A fall is observed in all the inequality and poverty indices, in particular those more sensitive to changes at the bottom of the distribution (Atkinson measure with an index value of 1.5, and the FGT poverty measures).

Table 9: Impact of Medical Card Expenditure on Inequality of Resources

\begin{tabular}{lccc}
\hline \hline $\begin{array}{l}\text { Inequality and } \\
\text { Poverty Indices }\end{array}$ & \multicolumn{2}{c}{ Value of the Index } \\
Pre-M.C. & $\begin{array}{c}\text { Post-M.C. } \\
\text { transfer }\end{array}$ & Transfer & $\begin{array}{c}\text { Change } \\
\%\end{array}$ \\
\hline Gini & 0.302 & 0.288 & -4.6 \\
Atkinson 0.5 & 0.074 & 0.067 & -9.3 \\
Atkinson 1.5 & 0.247 & 0.207 & -16.1 \\
FGT0 & 0.219 & 0.189 & -13.7 \\
FGT1 & 0.053 & 0.039 & -25.6 \\
FGT2 & 0.019 & 0.013 & -32.8 \\
\hline \hline
\end{tabular}

\section{EDUCATION}

The Irish educational system is organised into three levels:

- Primary schooling operates on an eight-year cycle, typically from age 5 to age 12 years. Primary schooling is compulsory.

- Second level schooling is compulsory for three years (the "Junior Cycle" or lower secondary), with a "Senior Cycle" (upper secondary) typically taking a further three years. 
- Third level education includes university primary degree courses (of 3 or 4 years duration), diploma courses of shorter duration, and postgraduate qualifications

We exclude the compulsory education years from our analysis, as it can be argued that the fact that education in these years is compulsory implies that the transfer of resources simply corresponds to a socially defined "need" for education. (See Section II for details.) Thus our analysis focuses on attributing benefits from free second level education and free third level education. It is well established that there are wage premia arising from participation in upper second level, and especially third level: Ireland is no exception in this regard (see, for example, Callan and Harmon, 1999). One could, therefore, seek to attribute the benefit of educational services provided to the individual, who will benefit from them in the labour market. This is an important perspective, but one which is very demanding from the point of view of data in principle it would require a picture of lifetime earnings. But there is another perspective, which is that benefit is also derived by parental households, who might otherwise pay fees for these educational services. Furthermore, to the extent that children end up in similar locations in the income distribution to their parents, attribution of benefits to the parental household can arrive at a similar outcome to the dynamic perspective. ${ }^{7}$

Figure 2: Current Public Expenditure per Student in Third Level Education (Constant 1995 Prices)

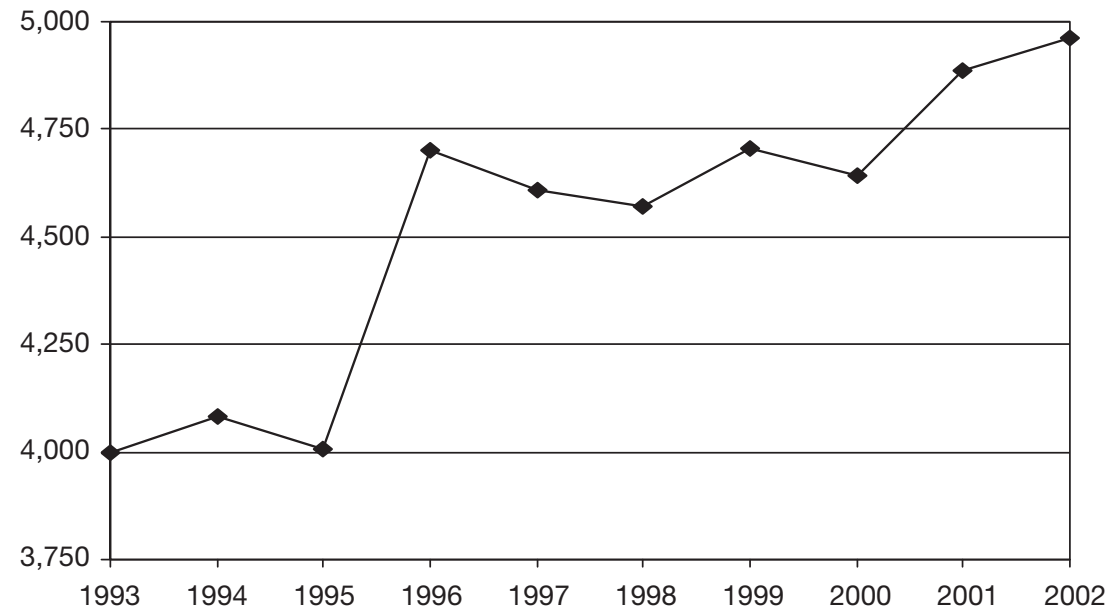

7 Where parents and children end up in different locations in the income distribution, one may note that if an individual from a poor household obtains a third level education, and consequently a higher income than his/her parents, this benefit under our analysis is attributed to poor households. 
As can be seen from the graph above government expenditure on third level education increased greatly in 1995 with the abolition of fees for undergraduate courses. The Table below shows the effect the inclusion of noncompulsory education has on various inequality and poverty measures.

Table 10 shows the changes in income shares per quintile once noncompulsory education is taken into account. We observe a rise in income shares of the bottom two quintiles with a slight fall in income share for the top quintile. Although the bottom two quintiles see increases in equivalised disposable income of 3.9 and 4.6 per cent the third and fourth quintiles also benefit with increases of more than 2 per cent. The top quintile sees an increase of around 1 per cent.

Table 10: Changes in Income Shares by Quintile Due to Non-Compulsory Education

\begin{tabular}{lccc}
\hline \hline $\begin{array}{c}\text { Quintile } \\
\text { Equivalised Disposable } \\
\text { Income Share } \\
\%\end{array}$ & $\begin{array}{c}\text { Income Share } \\
\text { Post-Transfer } \\
\%\end{array}$ & $\begin{array}{c}\text { \% Change in Equivalised } \\
\text { Disposable Income } \\
\%\end{array}$ \\
\hline 1 & 7.80 & 8.00 & 3.90 \\
2 & 12.90 & 13.10 & 4.60 \\
3 & 17.90 & 17.90 & 2.40 \\
4 & 23.60 & 23.60 & 2.10 \\
5 & 37.80 & 37.40 & 0.90 \\
Total & 100 & 100 & 2.20 \\
\hline \hline
\end{tabular}

Table 11 shows the impact spending on non-compulsory education has on inequality and poverty indicators. We see relatively small falls in all the indicators.

Table 11: Impact of Non-Compulsory Education Expenditure on Inequality of Resources

\begin{tabular}{lccc}
\hline \hline $\begin{array}{l}\text { Inequality } \\
\text { and poverty } \\
\text { indices }\end{array}$ & \multicolumn{2}{c}{ Value of the Index } \\
\cline { 2 - 3 } & $\begin{array}{c}\text { Pre NC Education } \\
\text { transfer }\end{array}$ & $\begin{array}{c}\text { Post NC Education } \\
\text { Transfer }\end{array}$ & $\begin{array}{c}\text { Change } \\
\%\end{array}$ \\
\hline Gini & 0.302 & 0.297 & 1.70 \\
Atkinson 0.5 & 0.074 & 0.072 & 3.20 \\
Atkinson 1.5 & 0.247 & 0.242 & 1.90 \\
FGT0 & 0.219 & 0.212 & 3.30 \\
FGT1 & 0.053 & 0.051 & 3.40 \\
FGT2 & 0.019 & 0.018 & 5.30 \\
\hline \hline
\end{tabular}




\section{NON-CASH RESOURCES AND THE DISTRIBUTION OF ECONOMIC WELFARE: COMBINED RESULTS}

Table 12 shows the changes in income shares per quintile when we take into account imputed rent, medical card expenditure and non-compulsory education provision. Overall we see the largest increase in equivalised disposable income in the bottom quintile and the smallest increase in the top quintile, the increase falling consistently as we move up the income distribution. We can, therefore, say that the non-cash benefits looked at in this paper are 'pro-poor'.

Table 12: Changes in Income Shares by Quintile Due to All Transfers

\begin{tabular}{lccc}
\hline \hline $\begin{array}{c}\text { Quintile } \\
\text { Equivalised Disposable } \\
\text { Income Share } \\
\%\end{array}$ & $\begin{array}{c}\text { Income Share } \\
\text { Post-Transfer } \\
\%\end{array}$ & $\begin{array}{c}\text { \% Change in Equivalised } \\
\text { Disposable Income } \\
\%\end{array}$ \\
\hline 1 & 7.8 & 9.0 & 33.2 \\
2 & 12.9 & 13.5 & 20.7 \\
3 & 17.9 & 17.9 & 14.1 \\
4 & 23.6 & 23.3 & 12.6 \\
\multirow{2}{*}{ Total } & 37.8 & 36.4 & 9.0 \\
\hline \hline
\end{tabular}

As we can see from Table 13 all the inequality and poverty measures listed all fall by substantial amounts, in particular those sensitive to movements at the bottom of the income distribution.

Table 13: Impact of All Transfers on Inequality of Resources

\begin{tabular}{lccc}
\hline \hline \multirow{2}{*}{$\begin{array}{l}\text { Inequality } \\
\text { and Poverty } \\
\text { Indices }\end{array}$} & \multicolumn{2}{c}{ Value of the Index } & \\
\cline { 2 - 3 } & Pre-transfers & Post-transfers & $\begin{array}{c}\text { Change } \\
\%\end{array}$ \\
\hline Gini & 0.302 & 0.276 & -8.6 \\
Atkinson 0.5 & 0.074 & 0.061 & -16.9 \\
Atkinson 1.5 & 0.247 & 0.173 & -30.0 \\
FGT0 & 0.219 & 0.163 & -25.5 \\
FGT1 & 0.053 & 0.032 & -39.6 \\
FGT2 & 0.019 & 0.010 & -47.1 \\
\hline \hline
\end{tabular}




\section{CONCLUSIONS}

Non-cash benefits can have substantial effects on the distribution of economic welfare. Standard approaches, however, have failed to take adequate account of the pattern of needs associated with the greater use of health and education services. Our results, for Ireland in the year 2000, show that it is possible to derive more appropriate measures of total resources than have been derived using standard methods. The results indicate that, as far as health, education and imputed rent are concerned the overall pattern of redistribution is "pro-poor".

\section{BIBLIOGRAPHY}

ANDERBERG, D., 2001. "Social Insurance with In-Kind Provision of Private Goods", Scandinavian Journal of Economics, Vol. 103, pp. 41-61.

ANTONINIS, M. and P. TSAKLOGLOU, 2001. "Who Benefits from Public Education in Greece? Evidence and Policy Implications", Education Economics, Vol. 9, pp. 197-222.

BALESTRINO, A., 1999. "The Desirability of In-Kind Transfers in the Presence of Distortionary Taxes", Journal of Economic Surveys, Vol. 13, pp. 333-354.

BESLEY, T. and S. COATE, 1991. "Public Provision of Private Goods and the Redistribution of Income", American Economic Review, 81, pp. 979-984.

BOADWAY, R. and M. KEEN, 2000. "Redistribution" in A. B. Atkinson and F. Bourguignon (eds.), Handbook of Income Distribution, Vol. 1, Amsterdam: ElsevierNorth Holland.

CALLAN, T., 1992. "Taxing Imputed Income from Owner-Occupation: Distributional Implications of Alternative Packages", Fiscal Studies, Vol. 13, pp. 58-70.

CALLAN, T. and C. HARMON, 1999. "The Economic Return to Schooling in Ireland", Labour Economics, Vol. 6, No. 4, pp. 543-550.

CALLAN, T., T. SMEEDING and P. TSAKLOGLOU, 2008. "Distributional Effects of Public Education Transfers in Seven European Countries", IZA Discussion Paper No. 3557.

CANBERRA GROUP, 2001. Final Report and Recommendations, The Canberra Group: Expert Group on Household Income Statistics, Ottawa.

COATE, S., S. JOHNSON and R. ZECKHAUSER, 1994. "Pecuniary Redistribution Through In-Kind Programs", Journal of Public Economics, Vol. 55, pp. 19-40.

CREMER, H. and F. GAHVARI, 1997. "In-Kind Transfers, Self-Selection and Optimal Tax Policy", European Economic Review, Vol. 41, pp. 97-114.

CURRIE, J., 1994. "Welfare and the Well-Being Of Children: The Relative Effectiveness of Cash and In-Kind Transfers", in J. M. Poterba (ed.), Tax Policy and the Economy, Vol 8, Cambridge MA: MIT Press.

DONALDSON, C., S. BIRCH and A. GAFNI, 2002. "The Distribution Problem in Economic Evaluation: Income and the Valuation of Costs and Consequences of Health Care Programmes", Health Economics, Vol. 11, pp. 55-70. 
EPPLE, D. and R. E. ROMANO, 1996. "Public Provision Of Private Goods", Journal of Political Economy, Vol. 104, pp. 57-84.

EUROSTAT, 1998. "Procedure for Calculating Imputed Rents", Working Group: Statistics on Income, Social Exclusion and Poverty. DOC.PAN103/1999. Luxembourg: Eurostat, December.

EUROSTAT, 2000. "Summary of Criticisms and Suggestions Concerning Methods of Calculating Imputed Rents", DOCPAN144/2000. Luxembourg: Eurostat, February.

EVANDROU, M. et al., 1992. "The Distribution of Welfare Benefits in Kind", Fiscal Studies, Vol. 14, No. 1.

FAHY, T. et al. 2004. "Housing Expenditures and Income Poverty in EU Countries", Journal of Social Policy, Vol. 33, No. 3, pp. 437-454.

FRICK, J. R. and M. GRABKA, 2003. "Imputed Rent and Income Inequality: A Decomposition Analysis for Great Britain, West Germany and the US". Review of Income and Wealth Vol.49, No.4, 513-537

FRICK, J. R., M. GRABKA and O. GROH-SAMBERG, 2007. "Estimates of Publicly Provided Health Services and Analysis of their Impact on Income Inequality and Poverty", Discussion Paper 734, DIW Berlin.

GARFINKEL, I., L. RAINWATER and T. M. SMEEDING, 2004. "Welfare State Expenditures and the Redistribution of Well-Being: Children, Elders and Others in Comparative Perspective", paper presented at the 2004 APPAM conference, Atlanta Georgia.

JACOBY, H. G., 1997. "Self-selection and the Redistributive Impact of In-Kind Transfers: An Econometric Analysis", Journal of Human Resources, Vol. 32, pp. 233-249.

JONES, A. and O. O'DONNELL, 1995. "Equivalence Scales and the Costs of Disability", Journal of Public Economics, Vol. 56, pp. 273-289.

JONES, F., 2006. "The Effects of Taxes and Benefits on Household Income, 2004-5". Published in web format for the Office of National Statistics. Available online at http://www.statistics.gov.uk.

LAYTE, R., A. NOLAN and B. NOLAN, 2007. Poor Prescriptions: Poverty and Access to Community Health Services, Dublin: Combat Poverty Agency.

LEGRAND, J., 1978. "The Distribution of Public Expenditure: The Case of Health Care", Economica, New Series, Vol. 45, No. 178.

MARICAL, F., M. MIRA D'ECOLE, M. VAALAVOU and G. VERBIST, 2006. "Publiclyprovided Services and the Distribution of Resources", OECD Social, Employment and Migration Working Paper No. 45, Paris: OECD.

MOFFITT, R., 1989. "Estimating the Value of an In-Kind Transfer: The Case of Food Stamps", Econometrica, Vol. 57, pp. 385-409.

MULLAN, K., H. SUTHERLAND and F. ZANTOMIO, 2007. "The Distributional Impact of Public Health Expenditure in the United Kingdom”, AIM-AP Project, Paper 1.3b.

MURPHY, D., 1984. "The Impact of State Taxes and Benefits on Irish Household Incomes". Journal of the Statistical \& Social Inquiry Society of Ireland, Vol 25, Part 1.

NOLAN, B., 1981. "Redistribution of Household Income in Ireland by Taxes and Benefits", The Economic and Social Review, Vol. 13, No. 1.

NOLAN, B. and H. RUSSELL, 2001. Non-Cash Benefits and Poverty in Ireland, Policy Research Series, No. 39, Dublin: The Economic and Social Research Institute. 
O'CONNELL, P., 1982. "The Distribution and Redistribution of Income in the Republic of Ireland", The Economic and Social Review, Vol. 13, No. 4.

O'HIGGINS, M., 1981. "The Distributive Effects of Public Expenditure and Taxation: An Agnostic View of the CSO Analyses", Review of Income and Wealth, Volume 27, Issue 3.

OSBERG, L., T. M. SMEEDING and J. SCHWABISH, 2004. "Income Distribution and Public Social Expenditure: Theories, Effects And Evidence” in K. Neckerman (ed.), Social Inequality, pp. 821-859, New York: Russell Sage Foundation.

RADNER, D., 1997. "Noncash Income, Equivalence Scales and the Measurement of Economic Well-Being", Review of Income and Wealth, Series 43, No. 1, pp. 71-88.

ROTTMAN, D. and M. REIDY, 1988. "Redistribution Through Social Expenditure in the Republic of Ireland". NESC Report No. 85, Dublin: NESC.

SAUNDERS, P., H. STOTT and G. HOBBES, 1991. "Income Inequality in Australia and New Zealand: International Comparisons and Recent Trends", The Review of Income and Wealth, Vol 37, Issue 1, pp. 63-79.

SEFTON, T., 2002. "Recent Changes in the Distribution of the Social Wage". Case Paper 62, Centre for Analysis of Social Exclusion.

SINGH, N. and R. THOMAS, 2000. "Welfare Policy: Cash Versus Kind, Self-Selection and Notches", Southern Economic Journal, Vol. 66, pp. 976-990.

SLESNICK, D. T., 1996. "Consumption and Poverty: How Effective are In-Kind Transfers?", Economic Journal, Vol. 106, pp. 1527-1545.

SMEEDING, T. M., P. SAUNDERS, J. CODER, S. P. JENKINS, J. FRITZELL, A. J. M. HAGENAARS, R. HAUSER and M. WOLFSON, 1993. "Poverty, Inequality and Living Standard Impacts Across Seven Nations: The Effects of Non-Cash Subsidies for Health, Education and Housing”, Review of Income and Wealth, Vol. 39, No. 3, pp. 229-256.

TSAKLOGLOU, P. and M. ANTONINIS , 1999. "On the Distributional Impact of Public Education: Evidence from Greece”, Economics of Education Review, Vol. 18, pp. 439-452.

VAN DAM, R., V. GEURTS and I. PANNECOUCKE, 2003. "Housing Tenure, Housing Costs and Poverty in Flanders (Belgium)", Journal of Housing and the Built Environment, Vol. 18, pp 1-23.

VAN DE WALLE, D. and K. NEAD (eds.), 1995. Public Spending and the Poor: Theory and Evidence, Baltimore and London: Johns Hopkins University Press.

VICARY, S. and T. SANDLER, 2002. "Weakest Link Public Goods: Giving In-Kind or Transferring Money?", European Economic Review, Vol. 46, pp. 1501-1520.

WOLFE, B. L. and R. MOFFITT, 1991. "A New Index to Value In-Kind Benefits", Review of Income and Wealth, Vol. 37, pp. 387-408.

YATES, J., 1994. "Imputed Rent and Income Distribution", Review of Income and Wealth, Vol. 40, pp 43-66. 


\section{APPENDIX \\ VALUATION METHODS AND WORKINGS}

\section{Imputed Rent}

There are three methods for calculating imputed rent; the market rent approach, the opportunity cost approach and the capital market method. The market rent approach looks at the rent paid on similar dwellings and attributes this value to imputed rent. The opportunity cost approach is similar but deducts owner related costs (such as interest, maintenance costs etc.) from the rental cost of similar properties. Finally, the capital market method recognises that investment in property results in the owner foregoing other investment opportunities that result in real income flows such as dividends from shares, interest from savings, etc. The capital market approach calculates a value for imputed rent by applying an 'interest rate' to the net equity value of the house (i.e. the market value of the house minus the outstanding mortgage amount, if any).

Due to the small number of private renters in the sample (see Table A1 below), standing at only 6.2 per cent, computing an accurate imputed rent figure using the market rent or opportunity cost approach would be difficult and unreliable. Therefore, we have used the capital market approach. For the purpose of our analysis we adopt a rate of 3 per cent in line with the rate chosen under the AIMAP (Accurate Income Measurement for the Assessment of Policies) project to facilitate cross-country comparison.

Table A1: Distribution of Tenure, Living in Ireland 2000.

\begin{tabular}{lr}
\hline Tenure & $\%$ \\
\hline Own outright & 39.7 \\
Own with mortgage & 44.8 \\
Local authority tenant & 7.7 \\
Private tenant & 6.2 \\
Other & 1.6 \\
All & 100.0 \\
\hline \hline
\end{tabular}

Note: Sample size for Living in Ireland Survey was 3,463 households.

Due to the small number of local authority tenants in the sample (7.7 per cent) and issues involved that can make it difficult to value the property (thus calculating the net equity value needed under the capital market approach) we focus only on owner-occupiers. In doing this we calculate an imputed rent figure for more than 90 per cent of the sample. As can be seen from Table A2 
the percentage increase in equivalised disposable income is highest for the poorer quintile and decreases as we move up to the higher quintile. As eligibility for local authority housing is income dependent inclusion of an imputed rent value for local authority tenants would reinforce this trend of larger gains for lower income quintiles. This is shown in Table A2 below where we see that the vast majority of social housing tenants are found in the bottom quintiles.

Table A2: Distribution of Tenure Within Quintiles of Disposable Income

\begin{tabular}{lccccc}
\hline \hline Quintile & Tenure within quintile & & & \\
& $\begin{array}{c}\text { Own } \\
\text { Outright } \\
\%\end{array}$ & $\begin{array}{c}\text { On } \\
\text { Mortgage } \\
\%\end{array}$ & $\begin{array}{c}\text { Social } \\
\text { Housing } \\
\%\end{array}$ & $\begin{array}{c}\text { Market } \\
\text { Rent } \\
\%\end{array}$ & $\begin{array}{c}\text { Rent free/ } \\
\text { Employer/Family } \\
\%\end{array}$ \\
\hline Bottom & 44.0 & 23.8 & 23.1 & 7.2 & 1.8 \\
2.00 & 44.1 & 40.0 & 9.5 & 5.2 & 1.2 \\
3.00 & 42.2 & 46.9 & 4.5 & 4.2 & 2.2 \\
4.00 & 38.4 & 52.8 & 1.6 & 5.9 & 1.3 \\
Top & 29.7 & 60.1 & .1 & 8.5 & 1.6 \\
All & 39.7 & 44.8 & 7.7 & 6.2 & 1.6 \\
\hline \hline
\end{tabular}

\section{Health}

We value two aspects of healthcare in this paper - first, the traditional approach of attributing all healthcare spending to Ireland's citizens and second, focusing on medical card spending. When looking at all healthcare spending we compute a value for various age groups calculated using public health care expenditures derived from the OECD Social Expenditure Database (SOCX). It encompasses expenditure on in-patient care, ambulatory medical services and pharmaceutical goods but does not include nonreimbursed individual health expenditures or cash benefits related to sickness. As can be seen in Figure A1 below, using the insurance-based approach, healthcare spending per capita increases with age, rising sharply above the age of 60 years.

We then go on to look at the income-contingent medical card. Using the cost per capita approach we attribute a value to each medical cardholder. In 2000, 1,148,055 people (including dependants) were covered by the medical card scheme (35 per cent of the population). We took the total spending under the GMS (General Medical Services scheme) for the year 2000, as shown below in Table A3. 
Figure A1: Public Healthcare Per Capita for Each Age Group, 2000

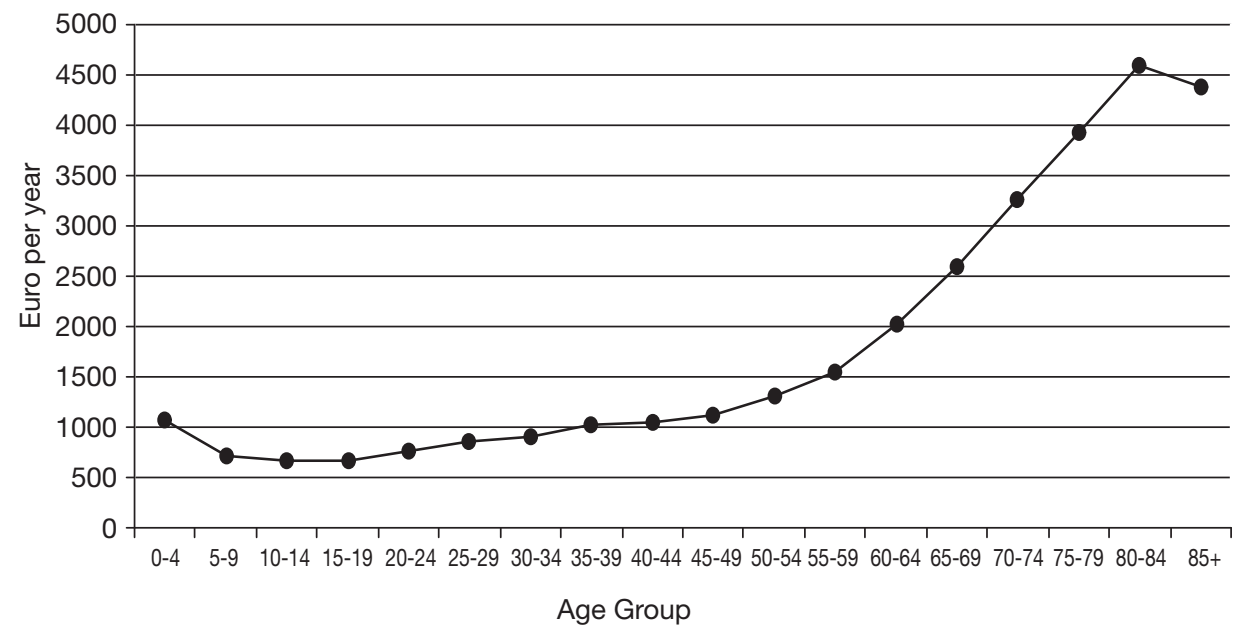

Table A3: GMS Spending in 2,000-Total and Per Medical Cardholder

\begin{tabular}{lr}
\hline \hline & 2000 \\
& $\in m$ \\
\hline Doctors' Fees & 113.88 \\
Allowances & 56.05 \\
Pharmacists' Fees \& Mark-up & 131.99 \\
Drugs \& Medicines & 395.61 \\
Reduction as per DPS eligibility 1 & 319.85 \\
Dentists & $\mathbf{( 7 5 . 7 6 )}$ \\
Investment In General Practice Development & 38.07 \\
& \\
High-tech Drugs Scheme & 10.22 \\
Payment to Wholesalers & \\
Patient Care Fees Paid to Pharmacists & 38.85 \\
Optometrists & 3.05 \\
Administration & \\
Total Payments for the Year & 11.78 \\
Total \# of Medical Cardholders (incl. dependants) & 742.43 \\
\hline Annual Value per Medical Cardholder & $1,148,055$ \\
\hline \hline
\end{tabular}

$1 € 140.7$ million was spent under the Drugs Payment Scheme in 2000. All non-medical cardholders are entitled to claim under the DPS; therefore we calculated the average spending per person eligible under the DPS and reduced the cost of drugs and medicines by this amount per medical cardholder. 
We then attributed this annual value of the medical card to each holder (and all dependants) in the sample.

\section{Education}

In order to maintain cross-country comparability we use the OECD "Education at a Glance" figures in our analyses. We exclude spending on research and development, which inflates the value of third level education per recipient. In our computation of the value of primary, secondary and tertiary we use the cost per capita basis. This equates to an annual value per student of $€ 3,291$ for primary students, $€ 4,407$ for secondary students and $€ 4,687$ for third level students. As we are focusing on non-compulsory education only we look at the senior cycle of secondary school and third level education. If a household member falls in the 16-18.5 year age category they are given the value for secondary level education. From the age of 18.5-22.5 years they are given the value of third level education.

Table A4: Public Expenditure Per Student by Education Level

\begin{tabular}{lcc}
\hline \hline $\begin{array}{l}\text { Education } \\
\text { Level }\end{array}$ & $\begin{array}{c}\text { Average Public Expenditure } \\
\text { Per Student (OECD) } \\
€ \text { Per Annum }\end{array}$ & \\
\hline Primary & 3,291 & Age Group \\
Secondary & 4,407 & $12.5-12.5$ years \\
& 4,687 & $16-18.5$ years (compulsory) \\
Tertiary & $48.5-22.5$ years \\
\hline \hline
\end{tabular}


